\title{
Sequence Stratigraphy and Sea Level Fluctuations of the Ab-Deraz Formation, Based on Palynological Evidence and Magnetic Susceptibility Method “Kopet-Dagh Sedimentary Basin, Northeastern Iran"
}

\author{
Farshid Yousefimoghadam ${ }^{*}$, Seyed Mahmood Hoseininezhad1, Mohsen Allameh ${ }^{2}$ \\ ${ }^{1}$ School of Geology Sciences, Damghan University, Damghan, Iran \\ ${ }^{2}$ Department of Geology, Mashhad Branch, Islamic Azad University, Mashhad, Iran \\ Email: hoseininezhad@yahoo.com, allameh.1345@yahoo.com, ${ }^{*}$ farshid.yousefimoghadam@gmail.com
}

Received 8 March 2015; accepted 7 May 2015; published 11 May 2015

Copyright (C) 2015 by authors and Scientific Research Publishing Inc.

This work is licensed under the Creative Commons Attribution International License (CC BY).

http://creativecommons.org/licenses/by/4.0/

(c) (i) Open Access

\section{Abstract}

Ab-deraz Formation is one of the Lithostratigraphic units of upper cretaceous (Middle TouronianSantonian) in Kopet-Dagh sedimentary basin, located in northeastern Iran. The aims of this study are separating sequence units and determining sea level Fluctuation by using palynological factors and comparison via magnetic susceptibility which is used for the first time in Ab-deraz Formation. Assuming the average MS magnitude as the proxy for mean sea level changes, positive Magnetic Susceptibility (MS) values were considered to present sea level falls and negative values for sea level rises. Based on these data a curve showing water level fluctuations throughout the stratigraphic column was prepared which shows a general trend of regression from base to the top of the formation. To test accuracy of this method, magnetic susceptibility results were compared with those gained from palynology and palynofacies studies. Based on the changes in palynological factors (the terrestrial/marine particles ratio, C/PPC ratio, diversity and abundance of dinoflagellate), palynofacies, for separate sequences, three sequences of the third type with four sequence boundaries, ( 3 boundaries of the type II and one boundary of the type I) were differentiated, confirming the results gained from magnetic susceptibility method.

\section{Keywords}

Sequence Stratigraphy, Magnetic Susceptibility, Ab-Deraz Formation, Kopeh-Dagh Basin

\footnotetext{
${ }^{*}$ Corresponding author.
}

How to cite this paper: Yousefimoghadam, F., et al. (2015) Sequence Stratigraphy and Sea Level Fluctuations of the Ab-Deraz Formation, Based on Palynological Evidence and Magnetic Susceptibility Method "Kopet-Dagh Sedimentary Basin, Northeastern Iran". Open Journal of Geology, 5, 268-280. http://dx.doi.org/10.4236/ojg.2015.55024 


\section{Introduction}

The Kopeh-Dagh sedimentary basin formed the middle Triassic orogeny in northeastern Iran [1]. There is no evidence of major tectonic activity in this region; all formations are conformable, except for a few disconformities within the cretaceous succession [2]. These disconformities can be related to epirogenic movement in the basin [3]. Sequence stratigraphy considers stratigraphic analysis and sea level fluctuations during depositional periods. This method considerably analyses the sequence migration and connection with time and sea level fluctuations [4]. Many factors have been used for sea level analysis. A relatively new method is using palynological elements and factors such as biological degradation of palynological particles, roundness and homogeneity of equidimensional phytoclasts [5], the relative abundance of opaque and semi opaque to transparent phytoclasts, the marine palynomorph/terrestrial particles ratio, relative abundance and diversity of dinoflagellate cysts and Chorate/Proximate, Proximochorate, Cavate (C/PPC) morphotype ratio [5]. These factors were used for sequence differentiation in this paper. Also organic substances are viewed as sedimentary components which reflect original condition in the source area and the depositional environments. The structure and quantity of these organic ingredients or kerogen deposited in marine palaeoenvironments were straightly connected to sea-level as shown by many researchers (e.g. [5]-[14]) who placed them in a sequence stratigraphic context. Magnetic susceptibility test provides information which makes independent evaluation and sequence stratigraphy modifications possible [15] and provides help for differentiation of exact boundaries in areas where no lithological differentiations recorded [15]. This paper aims to evaluate magnetic susceptibility role in sedimentary sequence analysis and for identification of sequence boundaries and system tracts. In order to test accuracy of this method magnetic susceptibility results have been used in conjunction and compared with palynology and palynofacies analysis.

\section{Geology Setting}

\subsection{Geographical Location}

The Kopeh-Dagh sedimentary basin stretches hundreds of kilometers from north to northwestern Iran and into Kazakhestan and Afghanestan. The Ab-Deraz Formation is one of the main upper cretaceous successions located in Kopeh-Dagh sedimentary bsin in northeastern Iran. The name of the Abdraz Formation originated from the Ab-Deraz village $75 \mathrm{~km}$ east of Mashhad and located in Muzdoran [1]. The west Sanganeh section (E: $\left.60^{\circ} 15^{\prime} 50^{\prime \prime}, \mathrm{N}: 36^{\circ} 41^{\prime} 15^{\prime \prime}\right)$ is located on the Mashhad-Kalat road, approximately $70 \mathrm{~km}$ from Kalat, and $2 \mathrm{~km}$ from Sanganeh village (Figure 1).

\subsection{Geology and Lithostratigraphy}

The lower contact of the Ab-Deraz Formation in Sanganehb section with the Aitamir Formation is paraconform, and the upper contact with the Ab-Talkh Formation is confirming. This section of the Ab-Deraz Formation is 530 meter thick. In these section lithology is composed of light gray shale, blueish shale, olive green shale and three chalky limestone bands (Figure 2).

\section{Material and Method}

The material used, includes 41 outcrop samples collected from shale and marly shale layer throughout the AbDeraz Formation (Sanganeh section). Laboratory maceration procedures of Travers (2007) were used to prepare sample. These procedures include chemical treatment of 15 - 20 gr of each sample with cold HCL (20\%) and HF (37\%) acids were used to dissolve carbonate and silicates. No oxidants or Alkalis were used, because such treatments can be affect the natural colors of palynomorphs and phytoclast. The residue was neutralized centrifuged in $\mathrm{Zncl}_{2}$ (specific gravity 1.9), then sieved 10 um using a nylon mesh, and mounted on microscope slides using liquid Canada balsam. Palynofacies analyses were also performed on these microscope slides. A total of 300 organic particles per sample were counted, classified, and proportionally calculated. Another portion of the same samples were analyzed by magnetic susceptibility meter MZ2 at Geophysics Institute of the University of Tehran. After preparation (powder providing in special case) MZ2 instrument have been adjusted in CGS system with low frequency and 0.1 oscillation.

The data in this paper obtained from magnetic susceptibility were compared with palynological data so that sequence unites could be separated and recognized. The comparison confirms that this method is quite appropriate for determining regressions and transgressions. 


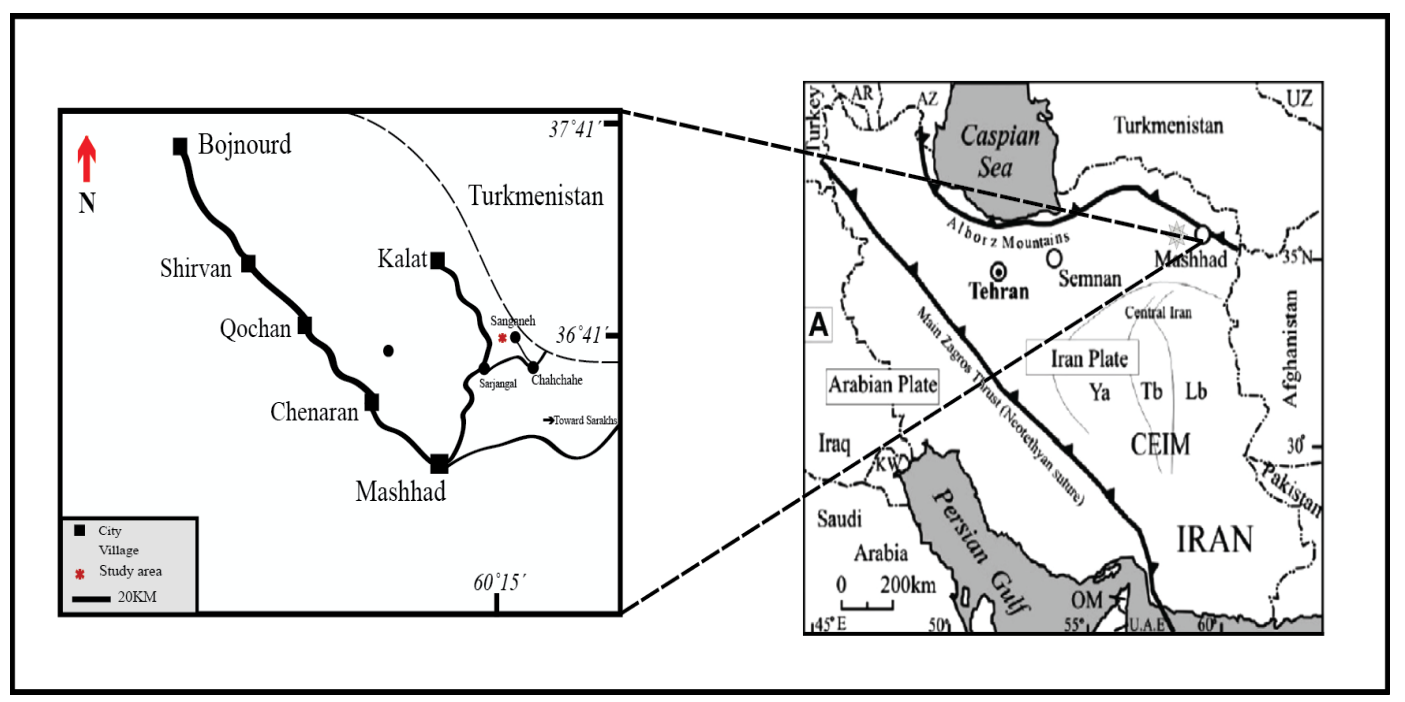

Figure 1. Location map of the studied section.

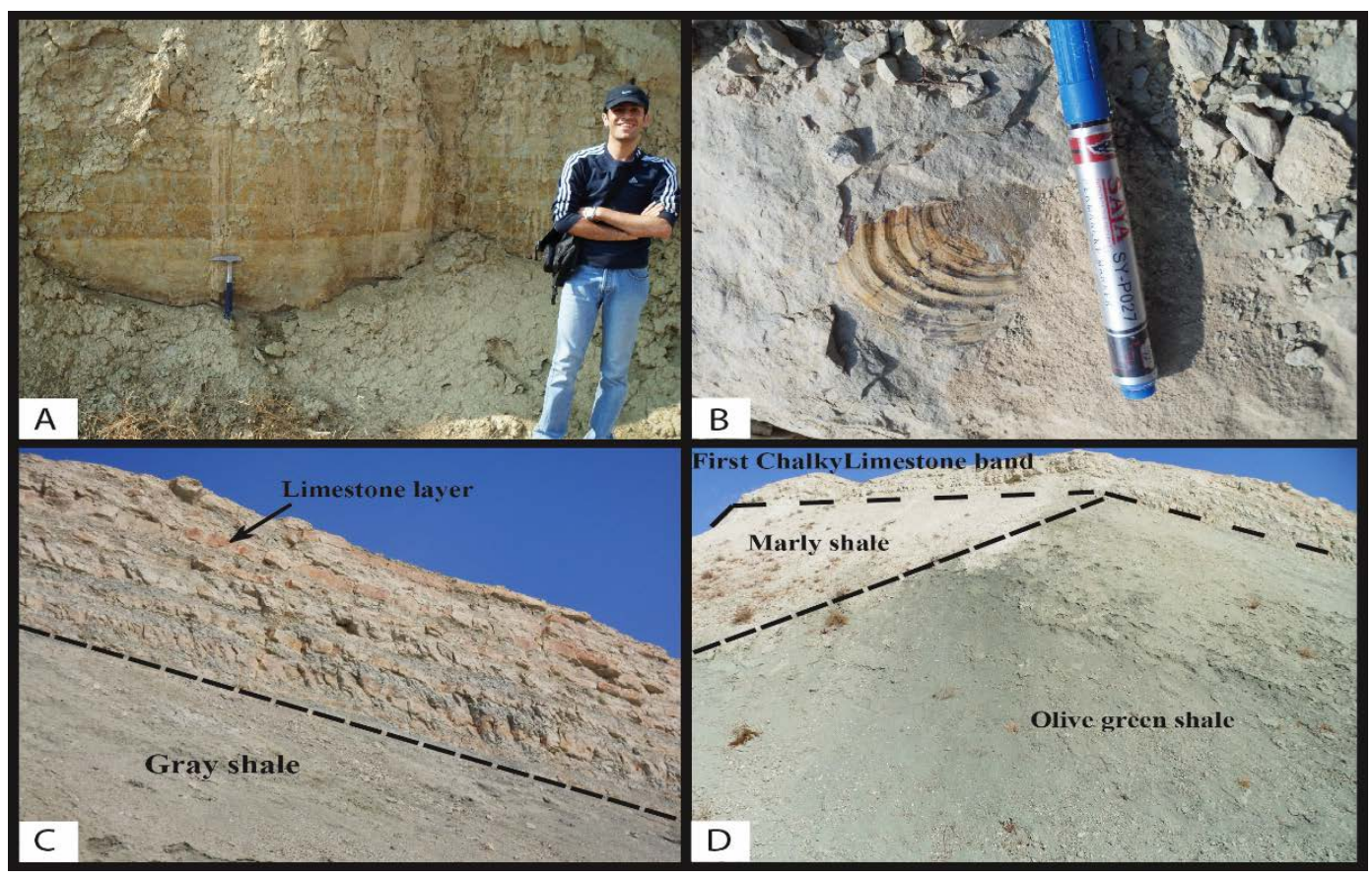

Figure 2. A-The lower contact, with the Aitamir Formation is paraconform; B-Inoceramids Fossils in limestone layer; C-Gray shale and limestone bands in Sanganeh section; D-Olive green shale with two Bound Chalky limestone in $240 \mathrm{~m}$ Thickness.

\section{Discussion}

Palynological factors affect the determination of sequence units. The reconstruction and interpretation of the sequence stratigraphy by facies unit palynology, three major groups of elements contained in the slides used Palynology, which includes frequency are palynomorphs (MP), amorphous organic matter (AOM) and the phytoclast (Ph) [12].

\subsection{Frequency of Amorphus Organic Matter}

Amorphous organic matter also use to determine the ecological interpretation and study of water sea level 
changes and the receding sequence units as the most important elements known to be. The relative abundance of AOM increases in a proximal to distal direction, and AOM is the dominant kerogen constituent in distal dysoxic to anoxic shelf environments [13]. The abundance of AOM increases during transgression and early highstand [16]. Such as Pallini et al. (1998) found that AOM is the main component at maximum flooding (Figure 3). The percentage of AOM in the Sanganeh section is shown in Figure 4 \& Table 1.

\subsection{Frequency of Phytoclast}

High percentage of phytoclast is mostly related to proximal depositional condition. Generally, large amount of phytoclast particles are deposited by rivers in estuaries and delta, both close to shorelines. However, re-depositional also accurse in deep waters by turbidity currents [16]. Phytoclast are generally divided into two categories: black and brown. Generally Black phytoclast therefore have an increased relative abundance in distal facies [5][20]. The relative abundance of brown phytoclast decreases in an offshore direction [17] [18] (Figure 3). The percentage of $P h$ in the Sanganeh section is show in Figure $4 \&$ Table 1.

\subsection{Frequency of Marine Palynomorph}

Identification and designation of marine palynomorphs, in particular dinoflagellates, in determining the sequence stratigraphy units and the have Paleoenvironment an important role. Increases the ratio of chorate to proximate, cavate and proximocavate form is show that the rise of water see level (Progressive conditions), and the increases the cavate form is show that to the fall of water see level (regressive conditions) [21] [37]. The percentage of $M P$ in the Sanganeh section is show in Figure 4 \& Table 1.

\section{Palynological Basis for Determination of Sequence Stratigraphy Units}

Conseptual models for palynofacies in sequence stratigraphy used to identify the system tracts on the basis of kerogen distribution were taken from Steffen and Gorine (1993), Tyson (1995) and Hart et al. (1994). The general trends of the key palynofacies parameters are show in Figure 3.

\subsection{Lowstand System Tract in Palynofacies}

The lowst and System tract (LST) is the lowest system tract in a sedimentary sequence. LST are clarified by

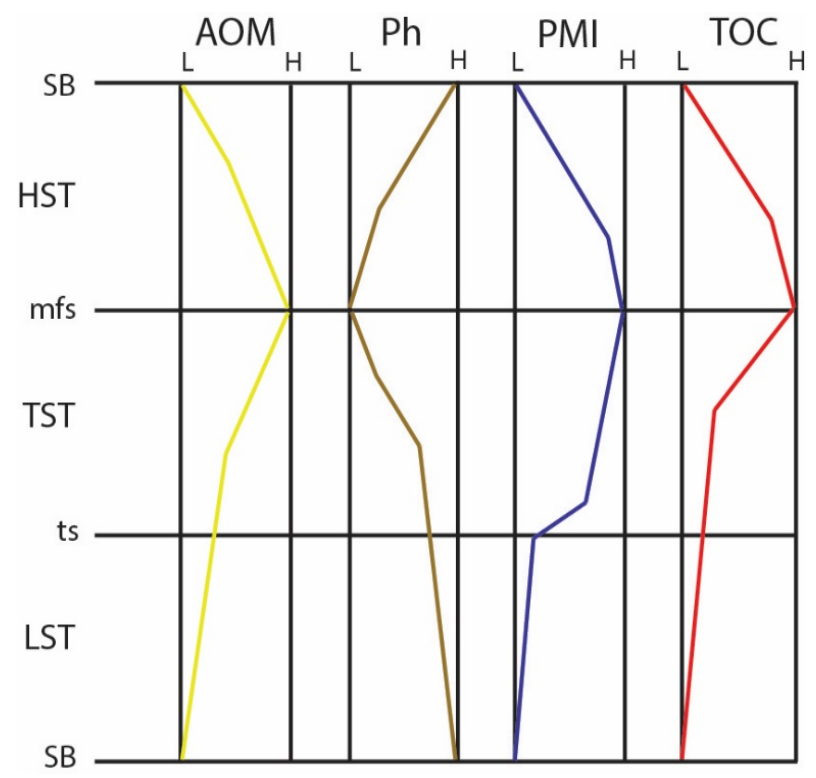

Figure 3. Schematic relation between organic matter abundances through a stratigraphic sequence (modified from Hart et al., 1994). SB = sequence boundary, ts = transgressive surface, mfs = maximum flooding surface, $\mathrm{LST}=$ lowstand systems tract, TST $=$ transgressive systems tract, $\mathrm{HST}=$ highstand systems tract, $\mathrm{AOM}=$ amorphous organic matter, $\mathrm{Ph}=$ phytoclasts, $\mathrm{PMI}$ = Palynological Marine Index, TOC = total organic carbon, $\mathrm{H}=$ high abundance, $\mathrm{L}=$ low abundance. 
Table 1. Palynological data for interpretation of water-level fluctuations (Figure 4): Amorphous organic matter (AOM), phytoclast (ph), marine palynomorph (MP), dinocyst diversity (Diversity), chorate/proximate, proximochorate, cavatedinocyst ratio (C/PPC), terrestrial particles/marine elements (CON/MAR), (ON/IN) outer neritic to inner neritic dinoflagellate ratio, (Fungal spore) Frequency of fungal spore measured magnetic susceptibility (MS), subtracting the average MS from each datum (Ms-6.25).

\begin{tabular}{|c|c|c|c|c|c|c|c|c|c|c|c|}
\hline S. No & $\mathrm{AOM}$ & $\mathrm{Ph}$ & MP\% & Diversity & $\mathrm{C} / \mathrm{PPC}$ & CON/MAR & Abundance & ON/IN & Fungal.sp & MS & MS-6.25 \\
\hline 1 & 31.25 & 68.75 & 0 & 0 & 0 & 78.25 & 0 & 0 & 0 & 7.79 & 1.54 \\
\hline 2 & 18.5 & 72.25 & 8.75 & 0 & 0 & 88.23 & 0 & 0 & 5 & 7.12 & 0.87 \\
\hline 3 & 8.75 & 72 & 19.25 & 0 & 31.56 & 81.87 & 26 & 46.87 & 15 & 7.03 & 0.78 \\
\hline 4 & 14 & 57.5 & 28.5 & 9 & 57.89 & 70 & 98 & 65.33 & 2 & 5.47 & -0.78 \\
\hline 5 & 33.75 & 49.25 & 16.75 & 21 & 67.41 & 61.24 & 143 & 58.70 & 5 & 4.02 & -2.23 \\
\hline 6 & 25.25 & 51.75 & 23 & 18 & 64.23 & 63.18 & 187 & 61.65 & 3 & 3.79 & -2.46 \\
\hline 7 & 11 & 37.25 & 52.5 & 11 & 70 & 40.29 & 235 & 85.13 & 0 & 4.03 & -2.24 \\
\hline 8 & 8.5 & 31.5 & 60 & 9 & 63.33 & 32.49 & 331 & 91.13 & 0 & 4.42 & -2.03 \\
\hline 9 & 5.75 & 37.5 & 56.75 & 9 & 68.89 & 35.51 & 218 & 77.33 & 0 & 3.25 & -3 \\
\hline 10 & 13.75 & 38.75 & 47.5 & 27 & 45.54 & 36.12 & 327 & 80.33 & 0 & 4.06 & -2.19 \\
\hline 11 & 16 & 34 & 50 & 29 & 39.36 & 38 & 211 & 86.96 & 0 & 4.42 & -2.03 \\
\hline 12 & 9.75 & 50.25 & 40 & 33 & 30.74 & 62.76 & 191 & 65 & 0 & 5.37 & -0.88 \\
\hline 13 & 23.5 & 60.25 & 16.25 & 0 & 18.23 & 71.23 & 39 & 34.48 & 25 & 5.60 & 0.65 \\
\hline 14 & 19 & 71.25 & 10.25 & 0 & 0 & 89.11 & 31 & 16.38 & 33 & 5.49 & 0.76 \\
\hline 15 & 13.25 & 36.75 & 50 & 34 & 42 & 47.16 & 296 & 86.49 & 1 & 4.89 & -1.36 \\
\hline 16 & 15.25 & 31.25 & 53 & 29 & 44 & 45.56 & 149 & 88.53 & 0 & 5.11 & -1.14 \\
\hline 17 & 24.25 & 28.75 & 47 & 33 & 41.29 & 39.65 & 104 & 74.45 & 0 & 4.68 & -1.57 \\
\hline 18 & 19.5 & 28.75 & 52.25 & 33 & 56.66 & 39.32 & 132 & 76.65 & 0 & 4.51 & -1.74 \\
\hline 19 & 30.5 & 20.25 & 49.25 & 33 & 54.32 & 31.33 & 117 & 75.33 & 0 & 4.65 & -1.85 \\
\hline 20 & 37 & 16 & 47 & 16 & 56.03 & 28 & 97 & 68.78 & 0 & 4.85 & -1.40 \\
\hline 21 & 10.5 & 24.5 & 65 & 19 & 23.12 & 37.92 & 265 & 65 & 0 & 3.26 & -2.99 \\
\hline 22 & 6 & 26.25 & 67.75 & 15 & 19.47 & 36.36 & 287 & 71.96 & 0 & 3.12 & -3.13 \\
\hline 23 & 13.25 & 51.5 & 35.25 & 26 & 34.41 & 68.75 & 210 & 51 & 0 & 4.02 & -2.33 \\
\hline 24 & 38.5 & 34.5 & 27 & 24 & 34.72 & 40.14 & 167 & 26.13 & 8 & 11.2 & 5 \\
\hline 25 & 16.5 & 74 & 9.5 & 0 & 0 & 87.34 & 26 & 31 & 17 & 10.7 & 4.95 \\
\hline 26 & 11.25 & 84.5 & 4.25 & 0 & 0 & 91.24 & 13 & 5.25 & 25 & 10.5 & 4.31 \\
\hline 27 & 25 & 24.5 & 50.5 & 21 & 64.04 & 36.66 & 309 & 90.18 & 0 & 7.21 & 0.96 \\
\hline 28 & 14.5 & 21.5 & 65 & 21 & 62.28 & 24 & 313 & 96.13 & 0 & 5.65 & -0.6 \\
\hline 29 & 14.25 & 16.75 & 69 & 26 & 65.12 & 23.43 & 336 & 97 & 0 & 3.87 & -2.38 \\
\hline 30 & 13 & 19.75 & 67.25 & 25 & 12.87 & 29.45 & 287 & 91.13 & 0 & 6.25 & 0 \\
\hline 31 & 23.5 & 31.5 & 44 & 31 & 56.16 & 43.76 & 145 & 85 & 0 & 5.63 & -0.62 \\
\hline 32 & 15.25 & 50.25 & 34.5 & 15 & 71.12 & 65.21 & 119 & 85.33 & 0 & 4.89 & -1.36 \\
\hline 33 & 3.5 & 66.25 & 30.25 & 19 & 69.46 & 76.52 & 94 & 76.14 & 0 & 4.96 & -1.29 \\
\hline 34 & 27.5 & 47.5 & 27 & 25 & 52.23 & 60.33 & 112 & 66.33 & 3 & 5.43 & -0.82 \\
\hline 35 & 6.5 & 73.5 & 20 & 25 & 54.32 & 80.05 & 81 & 54 & 21 & 5.53 & -0.72 \\
\hline 36 & 8.75 & 81.75 & 10 & 0 & 3.45 & 88.32 & 63 & 38.96 & 36 & 6.85 & 0.6 \\
\hline 37 & 13.75 & 38.75 & 47.5 & 24 & 46.85 & 46.96 & 189 & 68.44 & 0 & 4.84 & -1.41 \\
\hline 38 & 11.75 & 71.5 & 16.75 & 12 & 43 & 85 & 69 & 26.35 & 21 & 4.81 & -1.44 \\
\hline 39 & 9.75 & 81.75 & 8.5 & 0 & 0 & 89.76 & 36 & 20.13 & 34 & 5.29 & 0.96 \\
\hline 40 & 18.5 & 78.5 & 3 & 0 & 0 & 93.24 & 49 & 12.56 & 55 & 9.35 & 3.1 \\
\hline 41 & 7 & 91.75 & 1.25 & 0 & 0 & 97.54 & 10 & 0 & 68 & 10.4 & 4.17 \\
\hline
\end{tabular}




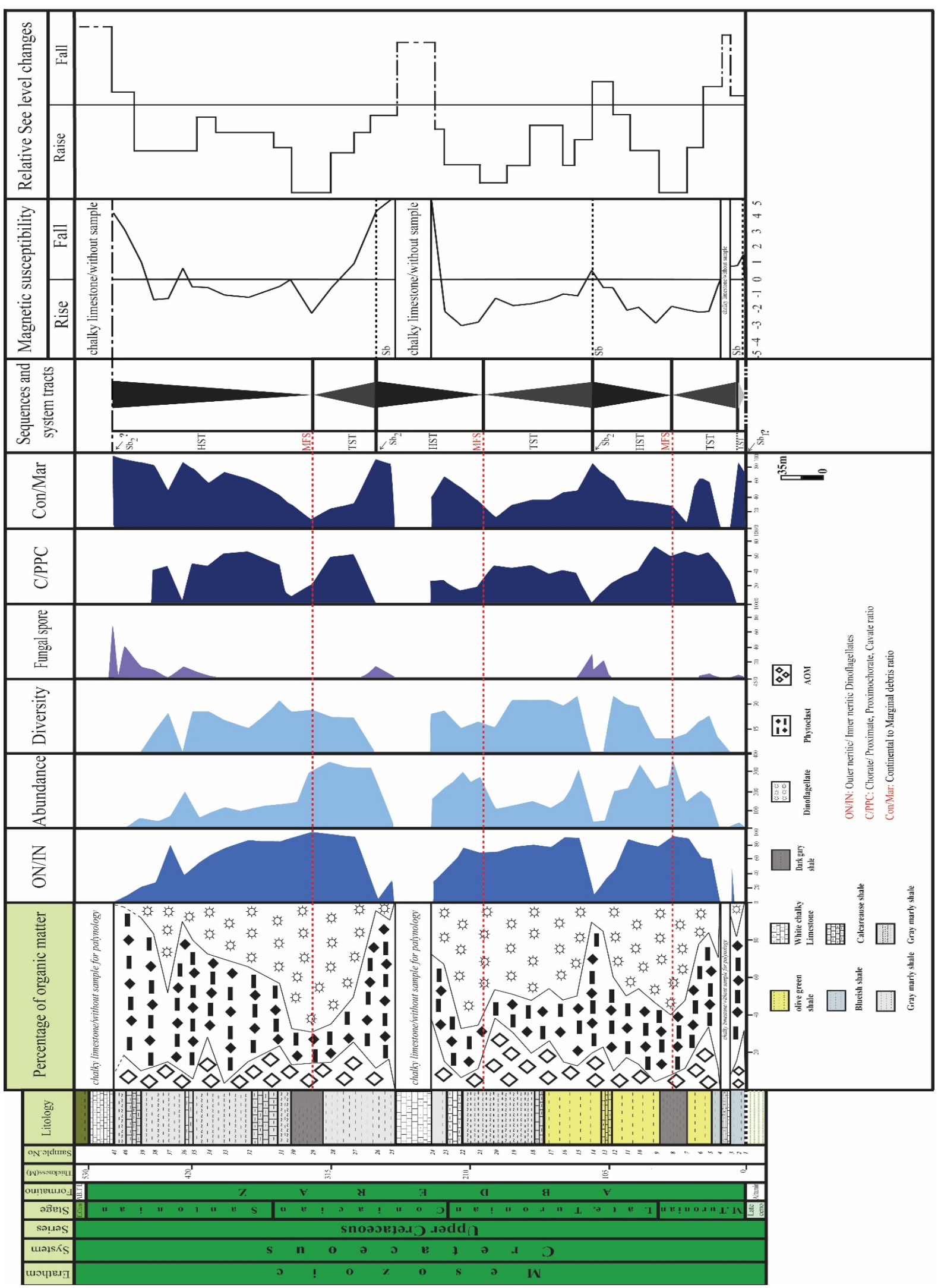

Figure 4. Palynological factors used to separate the sequences, in Sanganeh section. 
Progradational parasequnce set. In general, number of Phytoclasts increase in the LST in a way that there is high abundance of Phytoclasts in this part. The group of low stand facies is normally accompanied by facies near the source. Sediments of the dry land enters this place and thus, the abundance of marine Dinoflagellates decrease in this System Tract [4], morphotypes ratio of C/PPC face a reduction in these facies as well [21] (Figure 3).

\subsection{Transgressive System Tract in Palynofacies}

The Transgressive System Tract(TST) are clarified by Retrogradational parasequnce sets which move upward. At the time of Transgressive surface and water level rising rapidly, the abundance of Phytoclasts decrease, Dinoflagellates cyst abundance and diversity show a moderate growth. Amorphous organic matters and morphotypes ratio of C/PPC increase accordingly. On one hand, in upper parts of theTransgressiveSystemTract which is clarified by Maximum Flooding Surface, the amount of AOM, Dinoflagellates cysts and TOC reach their highest abundance. On the other hand, Phytoclasts reach their lowest abundance, however, Opaque maceral increases in abundance in the highest water level (MFS) and this trend prolongs to EHST tracts indicating the deepest marine facies (Figure 3).

\subsection{Highstand System Tract in Palynofacies}

The HST are the highest parts in a sequences which are primarily identified by Aggradational parasequnce sets and move upward and are shown by Progradational parasequnce set. At the time of the Highstand System Tract, first, the abundance and diversity of marine palynomorphs is high(EHST), then they show a descending trend (LHST), as a result, in the lowest part of the Highstand System tract, the lowest number of Phytoclasts is observed and a reduction occurs in the amount of AOM [4] (Figure 3).

\section{Magnetic Susceptibility}

Mineral particles are susceptible to becoming magnetized in the presence of a magnetic field, and MS is an index for the magnitude of this short-term magnetism within a sample [22]. Low-field MS, as is reported in many studies, is defined as the proportion of the induced moment (Mi or Ji) to the power of an applied, very low-intensity magnetic field $(\mathrm{Hj}$ ), where $\mathrm{Ji}=\mathrm{XijHj}$ (density-specific) or $\mathrm{Mi}=\mathrm{KijHj}$ (volume specific). In these phrases, MS in SI units is parameterized as $\mathrm{k}$, show that the calculation is comparative to a $1 \mathrm{~m}^{3}$ volume and is dimensionless; MS parameterized as X shows calculation comparative to a lump of $1 \mathrm{~kg}$ and is given in units of $\mathrm{m}^{3} / \mathrm{kg}$. However, as a general rule (with a few exceptions), during transgressive cycles, especially in distal marine sequences, MS is observed to decrease. This happens because detrital sediments are usually trapped near-shore during transgressions. During regressions, when erosion flushes detrital sediment into ocean basins and MS increases in basinal sediments [23]. MS is a quantitative measure of the amount of iron-bearing minerals in a sample [24] and as such is a rough proxy for the lithogenic or detrital fraction of marine sediment. It is important to note that MS data are very different from the magnetic polarities that record the magnetic properties of Earth's magnetic field in rocks, however, like magnetic polarities that depend on the preservation of iron in rocks, MS also depends on the preservation of iron-bearing minerals. Unlike magnetic polarities that can be easily remagnetized by heating, MS is largely unaffected by low to moderate thermal processes [25]. The MS has also been proven useful as a paleoclimatic indicator [26] [27] and thus for correlation purposes as a paleoclimate proxy [28]. One of the main applications of this method is in regional and global correlation [25]-[29]-[31]. The higher iron content represented by high MS magnitudes resulted from increased rates of weathering and delivery of paramagnetic minerals associated with a net fall in sea level [29]-[32]. The MS is known as a viable tool for correlating geological sequences [31]-[33].

\section{Result}

\subsection{Palynofacies}

Palynofacies contain all contents of Organic matter of sediments or sedimentary rocks [6]. Mixture and amount of these organic matters in the sedimentary environment is directly relevant to environmental changes. Thus, Palynofacies can be properly used to describe and reconstruct unexplainable or vague sequences [4]. In general, in order to determine palynological facies, three main factors are counted and assessed, namely, Marine paly- 
nomorph (MP), Amorphous organic matter (AOM), and Phytoclasts (Ph) [12]. Having Provided 82 palynological slides and counted 400 particles in each slide, main members (parts) were calculated and categorized. After plotting the data on the Tyson diagram, three Palynofacies, namely: II: Marginal disoxic-anoxic basin, IV: Shelf to basin transition, V: Mud dominated oxic shelf were identified which depicted marine environments near and off-shore with open marine environment having disoxic to suboxic conditions (Figure 5). Based on Figure 4, sample distribution in this section was more toward distal facies (Palynofacies type V). For instance, locating of samples 9, 21, and 29 around Palynofacies type V indicates that these shales are concentrated in anoffshore, and have disoxic to suboxic conditions. Thise parts appear containing a dark shale layer which differs from other parts in a lithological sense. Interpreting identified Palynofacies in this section, it can be stated that the highest abundance of Phytoclasts occurs in the upper and the end part of the section, namely, between Cenomanian to Turonian boundary and Santonian to Campanian boundary where the water level the most noticeable reduction (Aitamir to Ab-deraz Formation boundary in the lower part of the section and Ab-deraz Formation boundary to Ab-talkh Formation in the upper part of the Sanganeh Section this reduction in water level). Moreover, for instance, in samples 4, 15, and 27, the abundance of Dinoflagellates increases abruptly indicating that the water level has risen rapidly. Taking the abundance changes of Phytoclasts and marine palynomorphs into consideration, it can be stated that the water see level changes generally decreases while moving toward the end part of Ab-deraz Formation in this section.

\subsection{Sequence Stratigraphy}

Palynological factors such as the terrestrial/marine particles ratio, the chorate/proximate, proximochorate, cavate cyst ratio (C/PPC), differences in dinoflagellate assemblages [34] and rarity and abundance of dinoflagellate cyst groups were statistically calculated and used for sequence stratigraphic analysis. Based on This is information for separation and identification of the sequences units of the Ab-Deraz Formation in the West Sanganeh section and based on palynological evidence, lithology and field evidence three sequences of the third type with four sequence boundaries ( 3 boundaries of the type II and one boundary of the type I) were recognized for the Formation (Table 1 \& Figure 4).

\subsubsection{First Sequence}

This is limited to two sequence boundaries. The lower boundary is marked by a sharp change in lithology from sandstone to shale and chalky limestone. Based on field and palynological evidence, its lower boundary has
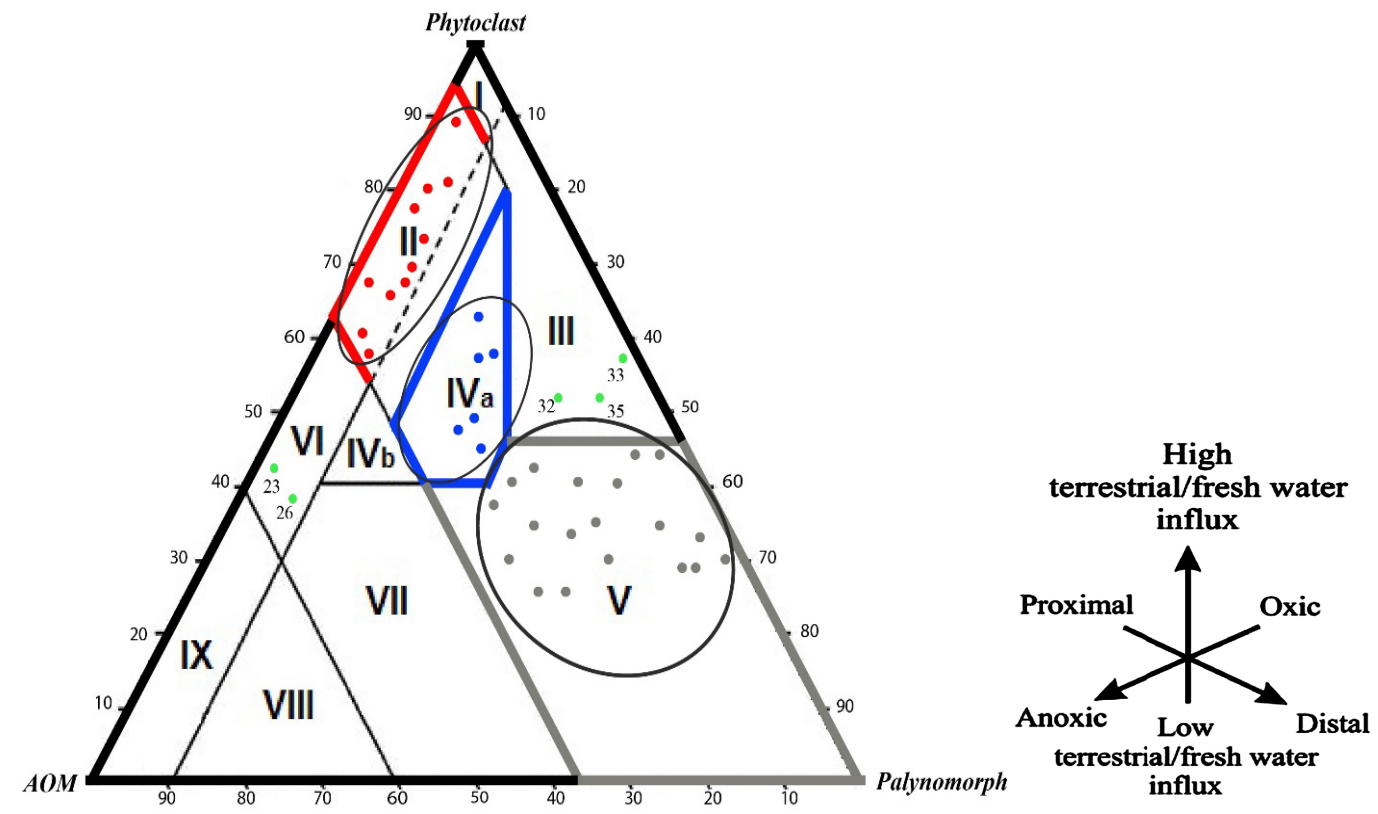

Figure 5. Studied samples plotted on ternary diagram based on their palynological contents [20]. 
discon formed with Aitamir Formation. The upper boundary is drawn at about 120 meters above the section and is marked by a sharp increase in phytoclasts, especially the brown phytoclasts, and a sharp decrease in marine palynomorph's abundance and diversity, a sharp decline in C/PPC and a sharp decline in ratio of ON/IN cyst. Three system tracts, LST, TST, and HST could also be differentiated within this sequence and its sediment environment changes from Marginal basin toward Distal shelf (Figure 4).

Lowstand System Tract: Deposited in a marginal basin. This tarct shows high level of brown phytoclast and low level of AOM. The highest amount of phytoclasts are recorded in the lowest parts of the LST. The relative abundance of marine palynomorphs (especially dinocysts) decreases in lowstand deposits. Such as in this limited $\mathrm{C} / \mathrm{PPC}$ ratio being low and also, Dinocysts of specific forms of Outer neritic (ON) to inner neritic (IN) ratio is low which shows the water level being low. According to field evidence, existence of a chalky limestone in this part shows that water level is moderately low.

Transgressive System Tract: The abundance of phytoclasts decrease, and the palynomorph diversity and $\mathrm{C} / \mathrm{PPC}$ ratio increase while ratio of terrestrial to marine elements decreases, such as in this limited relative amount of opaque maceral with rounded edge increase showing turbulent environment.

Maximum Flooding Surface: in this system tract which is identified at $80 \mathrm{~m}$ thick and by sample 9 , the highest abundance and diversity of Dinoflagellates marks the maximum flooding surface. Also a relative increase in abundance of AOM to phytoclasts and high amount of marine as compared to terrestrial elements occurs at the MFS. Based on field evidence, existence of a shale layer darker than other shales in this part of the stratigraphical row is an indicator of sedimentation in deep parts with low amount of energy.

Highstand system tract: in this limited, a process occurs opposite to system tract LST. The marine palynomorph and AOM ratio shows a reducing trend upwards. The abundance of phytoclasts, particularly the brown ones, increases and reaches its highest point in sequence boundary (from sample 9 to 14 and at $85 \mathrm{~m}$ to $120 \mathrm{~m}$ thick of the stratigraphical section under study). This system tract is deposited in a distal shelf.

\subsubsection{Second Sequence}

The lower boundary of this sequence is conformed with the upper boundary of the lower sequence. the upper boundary of this sequence is placed at some 275 meter above the base of the section. This boundary is identified by high abundance of phytoclasts and abrupt decraese in diversity and abundance of Dinoflagellates. Such as occure diversity and suuden decrease in the C/PPC ratio. Depositional environment changes from distal shelf to proximal shelf (Marginal basine) within the sequence. This sequence contains two system tracts of TST and HST as follows (Figure 4).

Transgressive System Tract: Deposited in a distal shelf, this system tract starts from sample 15 at 128 meter and lingers on to sample 21 at 200 meter. This tract shows decreasing the abundance of phytoclasts but diversity and abundance of Dinoflagellates increase. The C/PPC ratio increase too. Generally, in this level, marine particles increase when moving upward and opaque macerals with rounded edges will increase and that indicates off-shore environment. Also, the number of Dinoflagellates in outer neritic increase thus, reducing specific cysts of inner neritic decrease.

Maximum Flooding Surface: in this tract, the least number of phytoclasts and the most abundance and diversity of Dinoflagellates and AOM are observed (sample 22 at $220 \mathrm{~m}$ thick). This probably forms the deepest marine facies within this sequence. In addition, based on field evidence, this level is clarified by a shale layer and gray marl which is darker than the other parts and can be a sign of sedimentation in the deeper parts of the sea and there by a confirmation for palynological evidence.

Highstand System Tract: Depositional environment turns from distal shelf toproximal shelf (Figure 4). Diversity and abundance of palynomorphs and AOM have trend, while, the abundance of phytoclasts increase up to the point that in the highest level, the highest number of phytoclasts and in the lowest level, the lowest number of them is observed. These changes in the abundance and diversity of Dinoflagellates conform noticeably to stratigraphical evidence in stratigraphical rows and thus, show the impact of lithology on the abundance of Dinoflagellates. This means in shale samples, namely, sample 20 and 21, Dinoflagellates are highly abundant while they have the lowest abundance in marly and chalky samples (samples 23, 24, 25, and 26).

\subsubsection{Third Sequence}

The lower boundary of this sequence conforms with the upper boundary of the second sequence and the upper 
boundary at $530 \mathrm{~m}$ thick conforms to the third bands of chalky limestone, that is, sample 41 . Similar to the second sequence, this one too, is made up of two system tracts: TST and HST. It is worth mentioning that, based on the depth of the desired facies composition, (LST cannot be identified merely based on palynologicalevidence and thus, two system tracts, namely, LST and TST, are taken into consideration altogether) They are identifiable by the existent evidence in palynological slides (Figure 4).

Transgressive System Tract: Depositional environment in this tractis distal shelf. The water level has raised, the abundance of Dinoflagellates toward MFS increase. The relative amount of C/PPC and lability factor all decrease while, the marine palynomorph (Dinoflagellate) diversity and the ON/IN ratio increased. As well Opaque Macerals with the rounded edge in this tract showing turbulent and off-shore environment. (At $295 \mathrm{~m}$ thick to $320 \mathrm{~m}$ thick and in samples 27 and 28).

Maximum Flooding Surface: The maximum flooding surface is placed at the point of highest diversity and abundance of marine palynomorphs, especially Dinoflagellates. The AOM abundance has also increased from system tract TST toward this level eventually reaching its highest number. At this thickness, the highest number of outer neritic Dinoflagellates was observed and registered in comparison to inner neritic. This part is identifiable by a dark shale layer which shows sedimentation occurring in anoxic and low-energy condition.

Highstand System Tract: Depositional environment is distal shelf and changes into proximal shelf in upper parts. Based on field evidence and existence of thick calcareous layer of chalky limestone at the end part of Abderaz formation, this sequence boundary can be identified easily. Firstly, the abundance and diversity of marine palynomorphs increased. The following many factors for example C/PPC ratio marine elements diversity and ON/IN ratio shows a decreasing trend. This boundary that is, the last identified boundary conforming to the third calcareous layer of chalky limestone of the section under study, indicates relative sea level changes at $530 \mathrm{~m}$ thick. Yet it is worth mentioning that Ab-deraz formation boundary is conformed to Ab-Talkh formation in this section, and the latter, that is, Abtalkh formation, has not been discussed in this study, therefore, the fourth sequence boundary is determined by sample 41 under the third calcareous layer of chalky limestone.

\subsection{Magnetic Susceptibility}

In Figure 4 water-level fluctuations curve is drawn on the basis of magnetic susceptibility values recorded in the sediments. Assuming that the average MS magnitude for the region is a proxy for mean sea level, average MS is subtracted from each datum, positive MS values represent sea level fall and negative values represent sea level rise. By doing this, positive MS values (to the right of zero) represent magnitudes greater than the average and negative values (to the left of zero) represent magnitudes less than the average. It has been argued that the effects of sea level rise and fall, caused by either climate or tectonics or both, had the greatest effect on the supply of iron (Fe) to the depositional environments [32] [33].

It, therefore, seems reasonable to view positive values together with the associated higher concentrations of iron as a result of regression or a net fall in sea level. Negative values and associated lower concentration of iron would have been resulted from transgression or a net rise in sea level. Therefore, MS trend in Figure 4 demonstrates water-level fluctuations, in general. In this figure generally three phases of increase and decrease (shows by Dash line) in MS values occurs along the succession The general sequence boundaries are indicated. When compared with other graphs gained from measuring changes in palynological parameters it becomes evident that a reduction in the MS values is precisely correlatable with, in diversity and abundance of dinoflagellates, and in amorphous organic matter ratio. Also the ratio of morphotypes C/PPC increases. These are evidences for a rise in sea level. In contrast, increase in MS, is in accord with abundance of phytoclasts, decrease in diversity and frequency of marine palynomorphs, especially dinocysts, decrease in dinoflagellate morphotypes (C/PPC) ratio confirming a fall in water-level. Thus, the results of palynological studies confirm those of magnetic susceptibility (Figure 4).

\section{Conclusion}

The Ab-Deraz Formation studied for water sea level fluctuations, sequence stratigraphy and comparison to evaluate resolution of magnetic susceptibility. To test accuracy of this method, we used palynology and palynofacies process and change in organic matter contents and correlated for example: the terrestrial/marine particle ratios, the C/PPC ratio, diversity and abundances in dinoflagellate cysts, based on three main changes of organic materials (Phytoclasts, palynomorphs and amorphous organic materials) and integration of these data with iden- 
tified palynofacies, three sequences of the third type with four sequence boundaries (3 boundaries of type II and one boundary of the type I) were identified and determined. Magnetic susceptibility measured through the stratigraphic column shows in general a trend of falling water level which is in accord with increases in terrestrial elements and in increase with factors confirming a regression trend upwards. The data obtained from magnetic susceptibility were compared with palynological data so that sequence unites could be separated and recognized. The comparison confirms that this method is quite appropriate for determining regressions and transgressions.

\section{References}

[1] Afshar-Harb, A. (1994) Geology of KopetDagh. In: Hushmandzadeh, A., Ed., Treatise on the Geology of Iran, Geological Survey of Iran, Tehran, 275 p. (In Persian)

[2] Bretis, B., Grasemann, B. and Conradi, F. (2012) An Active Fault Zone in the Western KopehDagh (Iran). Austrian Journal of Earth Sciences, 105, 95-107.

[3] Oboh-Ikuenobe, F.E., Obi, C.G. and Jaramillo, C.A. (2005) Lithofacies, Palynofacies, and Sequence Stratigraphy of Palaeogene Strata in Southeastern Nigeria. Journal of African Earth Sciences, 41, 79-102. http://dx.doi.org/10.1016/j.jafrearsci.2005.02.002

[4] Carvalho, M.A., Mendonca Filho, J.G. and Menezes, T.R. (2006) Palynofacies and Sequence Stratigraphy of the AptianAlbian of the Sergipe Basin, Brazil. Sedimentary Geology, 192, 57-74. http://dx.doi.org/10.1016/j.sedgeo.2006.03.017

[5] Habib, D. and Miller, J.A. (1989) Dinoflagellate Species and Organic Facies Evidence of Marine Transgression and Regression in the Atlantic Coastal Plain. Palaeogeography, Palaeoclimatology, Palaeoecology, 74, 23-47. http://dx.doi.org/10.1016/0031-0182(89)90018-7

[6] Batten, D.J. (1996) Palynofacies and Palaeoenvironmental Interpretation. In: Jansonius, J. and McGregor, D.C., Eds., Palynology: Principles and Applications, Vol. 3, American Association of Stratigraphic Palynologists Foundation, College Station, TX, 1011-1064.

[7] Batten, D.J. and Stead, D.T. (2005) Palynofacies Analysis and Its Stratigraphic Application. In: Koutsoukos, E.A.M., Ed., Applied Stratigraphy, Springer, 203-226.

[8] Blondel, T.J.A., Gorin, G.E. and Jan du Chène, R. (1993) Sequence Stratigraphy in Coastal Environments: Sedimentology and Palynofacies of the Miocene in Central Tunisia. In: Posamentier, H.W., Summerhayes, C.P., Haq, B.U. and Allen, G.P., Eds., Sequence Stratigraphy and Facies Associations, The International Association of Sedimentologists, Vol. 18, 161-179. http://dx.doi.org/10.1002/9781444304015.ch9

[9] Bombardiere, L. and Gorin, G.E. (2000) Stratigraphical and Lateral Distribution of Sedimentary Organic Matter in Upper Jurassic Carbonates of SE France. Sedimentary Geology, 132, 177-203. http://dx.doi.org/10.1016/S0037-0738(00)00006-3

[10] Palliani, R.B., Cirilli, S. and Mattioli, E. (1998) Phytoplankton Response and Geochemical Evidence of the Lower Toarcian Relative Sea Level Rise in the Umbria-Marche BASIN (Central Italy), Palaeogeogr. Palaeogeography, Palaeoclimatology, Palaeoecology, 142, 33-50. http://dx.doi.org/10.1016/S0031-0182(97)00152-1

[11] Steffen, D. and Gorin, G. (1993) Sedimentology of Organic Matter in Upper Tithonian-Berriasian Deep-Sea Carbonates of Southeast France: Evidence of Eustatic Control. In: Katz, B. and Pratt, L., Eds., AAPG Studies in Geology Volume 37, 49-65.

[12] Tyson, R.V. (1995) Sedimentary Organic Matter: Organic Facies and Palynofacies. Chapman \& Hall, London, 615 p. http://dx.doi.org/10.1007/978-94-011-0739-6

[13] Tyson, R.V. (1996) Sequence-Stratigraphical Interpretation of Organic Facies Variations in Marine Siliciclastic Systems; General Principles and Application to the Onshore Kimmeridge Clay Formation, UK. In: Hesselbo, S.P. and Parkinson, D.N., Eds., Sequence Stratigraphy in British Geology, Vol. 103, Geological Society, London, Special Publications, 75-96. http://dx.doi.org/10.1144/GSL.SP.1996.103.01.06

[14] Van Wagoner, J.C., Posamentier, H.W., Mitchum, R.M., Vail, P.R., Sarg, J.F., Loutit, T.S. and Hardenbol, J. (1988) An Overview of the Fundamentals of Sequence Stratigraphy and Key Definitions. In: Wilgus, C.K., Hastings, B.S., Kendall, C.G., Posamentier, H.W., Ross, C.A. and Van Wagoner, J.C., Eds., Sea-Level Changes: An Integrated Approach, Vol. 42, The Society of Economic Paleontologists and Mineralogists, Special Publication, 39-45.

[15] Nagata, T. (1961) Rock Magnetism. Maruzen Company Ltd., Tokyo, 350 p.

[16] Hansen, H.J., Lojen, S., Toft, P., Dolenec, T., Tong, J., Michaelsen, P. and Sarkar, A. (2000) Magnetic Susceptibility and Organic Carbon Isotopes of Sediments across Some Marine and Terrestrial Permo-Triassic Boundaries. In: Yin, H., Dickins, J.M., Shi, G.R. and Tong, J., Eds., Permian-Triassic Evolution of Tethys and Western Circum-Pacific, Developments in Palaeontology and Stratigraphy, 18, 271-289. http://dx.doi.org/10.1016/S0920-5446(00)80016-3 
[17] Tyson, R.V. (1989) Late Jurassic Palynofacies Trends, Piper and Kimmeridge Clay Formations, UK Onshore and Northern North Sea. In: Batten, D.J. and Keen, M.C., Eds., Northwest European Micropalaeontology and Calynology, Ellis Horwood Publishers, Chichester, 135-172.

[18] Waveren, I. and Visscher, H. (1994) Analysis of the Composition and Selective Preservation of Organic Matter in Surfical Deep-Sea Sediment from a High Productivity Area (Banda Sea, Indonesia). Palaeogeography, Palaeoclimatology, Palaeoecology, 112, 85-111. http://dx.doi.org/10.1016/0031-0182(94)90135-X

[19] Thoa, N.T.K., Huyen, D.T., Ellwood, B.B., Lan, L.T.P. and Truong, D.N. (2004) Determination of Permian-Triassic Boundary in Limestone Formations from Northeast of Vietnam by Paleontological and MSEC Methods. Journal of Earth Science, 26, 222-232.

[20] Tyson, R.V. (1993) Palynofacies Analysis. In: Jenkins, D.J., Ed., Applied Micropalaeontology, Kluwer Academic Publishers, Dordrecht, 153-191. http://dx.doi.org/10.1007/978-94-017-0763-3_5

[21] Gorin, G.E. and Steffen, D. (1991) Organic Facies as a Tool for Recording Eustatic Variations in Marine Fine-Grained Carbonates-Examples of the Berriasian Stratotype at Berrias (Ardèche, SE France). Palaeogeography, Palaeoclimatology, Palaeoecology, 85, 303-320. http://dx.doi.org/10.1016/0031-0182(91)90164-M

[22] Ellwood, B.B., Garcia-Alcalde, J.L., El Hassani, A.E., Hladil, J., Soto, F.M., Truyols-Massoni, M., Weddige, K. and Koptikova, L. (2006) Stratigraphy of the Middle Devonian Boundary: Formal Definition of the Susceptibility Magnetostratotype in Germany with Comparisons to Sections in the Czech Republic, Morocco and Spain. Tectonophysics, 418, 31-49. http://dx.doi.org/10.1016/j.tecto.2005.12.012

[23] Ellwood, B.B., Tomkin, J.H., Ratcliffe, K.T., Wright, M. and Kafafy, A.M. (2008) High-Resolution Magnetic Susceptibility and Geochemistry for the Cenomanian/Turonian Boundary GSSP with Correlation to Time Equivalent Core. Palaeogeography, Palaeoclimatology, Palaeoecology, 261, 105-126. http://dx.doi.org/10.1016/j.palaeo.2008.01.005

[24] Nowrouzi, G., Priestley, K.F., Ashtiany, M.-G., Doloei, G.J. and Rham, D.J. (2007) Crustal Velocity Structure in Iranian Kopeh-Dagh, from Analysis of P-Waveform Receiver Functions. JSEE, 8, 187-194.

[25] Crick, R.E., Ellwood, B.B., El Hassani, A.E., Hladil, J., Hrouda, F. and Chlupac, I. (2001) Magnetostratigraphy Susceptibility of the Pridoli-Lochkovian (Silurian-Devonian) GSSP (Klonk, Czech Republic) and a Coeval Sequence in Antiatlas Morocco. Palaeogeography, Palaeoclimatology, Palaeoecology, 167, 73-100. http://dx.doi.org/10.1016/S0031-0182(00)00233-9

[26] Curry, W.B., Schneider, D.A. and Party, L.S. (1995) Ceara Rise Sediments Document Ancient Climate Change. EOS, 76, 40-45.

[27] Shackleton, N.J., Crowhurst, S.J., Weedon, G.P. and Laskar, J. (1999) Astronomical Calibration of Oligocene-Miocene Time. Philosophical Transactions of the Royal Society A, London, 357, 1907-1929. http://dx.doi.org/10.1098/rsta.1999.0407

[28] Sluijs, A., Pross, J. and Brinkhuis, H. (2005) From Greenhouse to Icehouse; Organic-Walled Dinoflagellate Cysts as Paleoenvironmental Indicators in the Paleogene. Earth-Science Reviews, 68, 281-315. http://dx.doi.org/10.1016/j.earscirev.2004.06.001

[29] Crick, R.E., Ellwood, B.B., El Hassani, A.E., Feist, R. and Hladil, J. (1997) Magnetosusceptibility Event and Cyclostratigraphy (MSEC) of the Eifelian-Givetian GSSP and Associated Boundary Sequences in North Africa and Europe. Episodes, 20, 167-175.

[30] Ellwood, B.B., Crick, R.E., El Hassani, A.E., Benoist, S.L.R.H. and Young, R.H. (2000) Magnetosusceptibility Event and Cyclostratigraphy (MSEC) Method Applied to Marine Rocks: Detrital Input versus Carbonate Productivity. Geology, 28, 1134-1138. http://dx.doi.org/10.1130/0091-7613(2000)28<1135:MEACMA>2.0.CO;2

[31] Ellwood, B.B., Crick, R.E., Garcia-Alcalde, F.J.L., Soto, F.M., Truyols-Massoni, M., El Hassani, A.E. and Kovas, E.J. (2001) Global Correlation Using Magnetic Susceptibility Data from Lower Devonian Rocks. Geology, 29, 583-586. http://dx.doi.org/10.1130/0091-7613(2001)029<0583:GCUMSD>2.0.CO;2

[32] Ellwood, B.B., Crick, R.E. and El Hassani, A.E. (1999) The Magnetosusceptibility Event and Cyclostratigraphy (MSEC) Method Used in Geological Correlation of Devonian Rocks from Anti-Atlas Morocco. AAPG Bulletin, 83, 1119-1134.

[33] Ellwood, B.B., MacDonald, W.D., Wheeler, C. and Benoist, S.L. (2003) The K-T Boundary in Oman: Identified Using Magnetic Susceptibility Field Measurements with Geochemical Confirmation. Earth and Planetary Science Letters, 206, 529-540. http://dx.doi.org/10.1016/S0012-821X(02)01124-X

[34] Steffen, D. and Gorin, G. (1993) Palynofacies of the Upper Tithonian-Berriasian Deep-Sea Carbonates in the Vocotian Trough (SE France). Bulletin Des Centres De Recherches Exploration-Production Elf Aquitaine, 17, 235-247.

[35] Traverse, A. (2007) Paleopalynology. 2nd Edition, Springer, Berlin, 816 p.

[36] Tyson, R.V. (1987) The Genesis and Palynofacies Characteristics of Marine Petroleum Source Rocks. In: Brooks, J. and Fleet, A.J., Eds., Marine Petroleum Source Cocks, Geological Society London Special Publications, 26, 47-67. 
[37] Ghasemi-Nejad, E., Sarjeant, W.A.S. and Gygi, R. (1999) Palynology and Palaeoenvironment of Uppermost Bathonian and Oxfordian (Jurassic) of the Northern Switzerland Sedimentary Basin. Kommission der Schweizerschen Palaontologischen Abhandlungen, Basel, 119, 69 p. 